\title{
Diminished Acoustic Startle in Chronic Cocaine Users
}

Toby R. Efferen, M.S., Erica J. Duncan, M.D., Sandor Szilagyi, B.S., Subhajit Chakravorty, M.D., Jill U. Adams, Ph.D., Stephen Gonzenbach, Ed.D., Burt Angrist, M.D., Pamela D. Butler, Ph.D., and John Rotrosen, M.D.

Chronic cocaine use has been shown to produce neurochemical alterations which persist after acute withdrawal. This study assessed the effects of cocaine use on the acoustic startle response and sensorimotor gating using prepulse inhibition (PPI) of startle. Nine male control subjects (mean age $=41.6$ ) and 15 male cocaine users (mean age $=43.2$ ) were tested, the latter after heavy cocaine use ranging from 4 to 27 years (mean age $=16.7$ ). Cocaine users had been cocaine free for four days to six months (mean $=17$ days) at testing. Cocaine users exhibited a $68 \%$ reduction in startle amplitudes $(F=7.4 ; d f=1,22 ; p<$
.01) compared to controls. There were trends towards increased PPI in cocaine users under certain conditions; however, there were no significant main effects. These results indicate that chronic cocaine use produces impairment of the startle response which persists after cessation of cocaine use. These findings may reflect changes in the dopaminergic system resulting from chronic cocaine use. [Neuropsychopharmacology 22:89-96, 2000] (C) 1999 American College of Neuropsychopharmacology. Published by Elsevier Science Inc.
KEY WORDS: Cocaine; Acoustic startle; Dopamine; Prepulse inhibition; Gating; Human

Chronic cocaine use causes physiological and neurochemical alterations which persist well after drug cessation. At the commencement of abstinence, adaptive decreases in dopamine (DA) receptor density (Kleven et al. 1990; Laurier et al. 1994) and DA uptake (Izenwasser and Cox 1990), as well as increases in DA transporter (DAT) mRNA expression (Pilotte et al. 1994; Wamsley and Alburges 1993) and cocaine binding sites (Malison et al. 1998), have been reported. As abstinence contin-

From the School of Medicine (TRE, EJD, SS, JUA, BA, PDB, JR) New York University, New York, NY; New York Veterans Affairs Medical Center, New York, NY (TRE, EJD, SS, JUA, SG, BA, JR); University of Pittsburgh and Western Psychiatric Institute and Clinic, Pittsburgh, PA (SC); Nathan S. Kline Institute for Psychiatric Research, New York, NY (PDB).

Address correspondence to: Erica J. Duncan M.D., Dept. of Psychiatry 116a, New York Veterans Affairs Medical Center, 423 East $23^{\text {rd }}$ St., New York, NY 10010.

Received March 26, 1999; revised July 21, 1999; accepted July 23, 1999 ues, there are decreases in basal DA efflux (Parsons et al. 1991; Weiss et al. 1992), DAT mRNA expression (Pilotte et al. 1994), DAT in nucleus accumbens (Wilson et al. 1994), and $D_{1}$ receptor density (Kleven et al. 1990), leading to an overall state of decreased dopaminergic neurotransmission (Kuhar and Pilotte 1996).

The acoustic startle response under observation in this study is a well characterized response consisting of a reflexive contraction of the skeletal musculature in response to an intense, abrupt stimulus. It is mediated by a simple 3-synapse subcortical circuit (Davis et al. 1982; Koch et al. 1993). In humans, the response is quantified using electromyographic (EMG) measurements of the obicularis oculi facial muscle (Hoffman and Searle 1968). This response is sensitive to dopaminergic modulation. Direct and indirect DA agonists, such as apomorphine, cocaine and d-amphetamine, increase startle amplitude in animals (Kehne and Sorenson 1978; Davis 1980; Johansson et al. 1995), whereas DA antagonists such as haloperidol and clozapine reduce startle amplitude (Mansbach et al. 1988; Johansson et al. 1995). 
The acoustic startle response can be attenuated if a weak, non-startling prestimulus (a prepulse) immediately precedes the startle stimulus (Graham 1975; Braff et al. 1992). This phenomenon is known as prepulse inhibition of startle (PPI), the pharmacology of which has been well characterized in animal studies. Dopamine agonists, both direct and indirect, reduce or eliminate PPI; D2 antagonists reverse the effect of agonists such as apomorphine (Mansbach et al. 1988). On the other hand, D1 antagonism fails to reverse the effect (Swerdlow et al. 1991).

The aim of the present study was to examine the functional consequences of long-term cocaine use by studying the acoustic startle response and PPI of the acoustic startle response during abstinence following prolonged cocaine use.

\section{MATERIALS AND METHODS}

\section{Subjects}

Sixty cocaine subjects and 20 normal individuals were screened in consideration for participation. Nine healthy male normal controls and 15 male cocaine users were enrolled in the study after signing a VA/NYU IRB approved consent form.

All subjects were screened to rule out presence or history of psychiatric or medical pathology (excluding substance induced disorders for the cocaine users) using the Structured Clinical Interview for the DSM-IV, Axis-1 (SCID-1). Subjects were also screened and excluded for left-handedness by means of a Handedness Inventory. All subjects had normal otoscopic examination and intact auditory function by audiometer testing (Grason Stadler GS 10 Clinical Audiometer) to determine pure tone thresholds from $250 \mathrm{~Hz}$ to $4 \mathrm{kHz}$.

Cocaine subjects with a usage history characterized by a minimum of six months of at least $\$ 50$ per day or weekly binges of at least $\$ 200$ of cocaine use and a urine sample negative for cocaine at the time of testing were enrolled. All cocaine subjects were questioned about amount of cocaine used in the thirty days prior to testing. Days since last use of cocaine, years of use, and approximate amount spent per use were assessed via the Addiction Severity Index (ASI) and confirmed by urine toxicology (Table 1). Clinical status at the time of testing was assessed with the Cocaine Abstinence Symptoms Scoring Sheet (CASSS), a 0-3 scored scale with subjective and objective components (Wolfsohn et al. 1993); the Brief Substance Craving Scale, which assessed craving for cocaine over the previous 24 hours; and a clinical scale for sensitization assessment (Bartlett et al. 1997), which provided information about changes over time with regard to subjective aspects of cocaine use such as euphoria, libido, hallucinations, and referential-
Table 1. Demographic Data Mean ( \pm SEM)

\begin{tabular}{|c|c|c|}
\hline Subjects & Cocaine Users & Normal Controls \\
\hline$N$ & 15 & 9 \\
\hline \multicolumn{3}{|l|}{ Age } \\
\hline Range & 33-62 years & $27-57$ years \\
\hline Mean $( \pm$ SEM $)$ & $43.2( \pm 2.1)$ years & $41.6( \pm 3.7)$ years \\
\hline Amt spent per week & & NA \\
\hline Range & $\$ 45-800$ & \\
\hline Mean ( \pm SEM $)$ & $\$ 253.70( \pm \$ 52.30)$ & \\
\hline $\begin{array}{l}\text { Amt spent in past } \\
30 \text { days }\end{array}$ & & NA \\
\hline Range & $\$ 0-2100$ & \\
\hline Mean ( \pm SEM) & $\begin{array}{l}\$ 1213.20 \\
\quad( \pm \$ 319.95)\end{array}$ & \\
\hline $\begin{array}{l}\text { Days used out of past } \\
\text { thirty }\end{array}$ & & NA \\
\hline Range & 0-20 days & \\
\hline Mean $( \pm$ SEM $)$ & $14.1( \pm 5.0)$ days & \\
\hline Years of regular use & & NA \\
\hline Range & 5-30 years & \\
\hline Mean $( \pm$ SEM $)$ & $16.7( \pm 1.7)$ years & \\
\hline Washout & & NA \\
\hline Range & 4-180 days & \\
\hline Mean ( \pm SEM) & $17.7( \pm 11.6)$ days & \\
\hline
\end{tabular}

ity (see Tables 2 and 3). The cocaine subjects were enrolled in inpatient $(n=12)$ or outpatient $(n=3)$ cocaine abuse treatment programs at the New York VA Medical Center at the time of testing.

\section{Startle Testing}

Acoustic startle testing was carried out with an EMG startle response system (SR-LAB; San Diego Instruments, San Diego, CA). Auditory startle responses were elicited using the following stimuli: 1) Pulse Alone, a $40 \mathrm{msec}$ pulse of 116 $\mathrm{dB}[\mathrm{A}]$ pure tone; 2) $75 \mathrm{~dB}[\mathrm{~A}]$ prepulse, a $75 \mathrm{~dB}[\mathrm{~A}], 20 \mathrm{msec}$ prepulse of pure tone followed by the $116 \mathrm{~dB}$ pulse, with an interstimulus interval of $100 \mathrm{msec}$; 3) $80 \mathrm{~dB}[\mathrm{~A}]$ prepulse, an $80 \mathrm{~dB}[\mathrm{~A}] 20 \mathrm{msec}$ prepulse of pure tone followed by the $116 \mathrm{~dB}[\mathrm{~A}]$ pulse; and 4) $85 \mathrm{~dB}[\mathrm{~A}]$ prepulse, an $85 \mathrm{~dB}[\mathrm{~A}]$

Table 2. CASSS Abstinence Data: Number Reporting Symptoms (Out of 15 Subjects) at Time of Testing

\begin{tabular}{lrccc}
\hline Measure & None & Mild & Moderate & Severe \\
\hline Sweating & 12 & 1 & 2 & 0 \\
Suspiciousness & 12 & 3 & 0 & 0 \\
Jittery & 8 & 4 & 2 & 1 \\
Irritable & 9 & 4 & 1 & 1 \\
Hypersomnia & 10 & 2 & 2 & 1 \\
Insomnia & 8 & 3 & 3 & 1 \\
Hopelessness & 8 & 0 & 7 & 0 \\
Inadequacy & 8 & 5 & 2 & 0 \\
Weakness & 8 & 5 & 2 & 0 \\
Fatigue & 9 & 1 & 4 & 1 \\
Disinterest & 8 & 2 & 5 & 0 \\
\hline
\end{tabular}


Table 3. Sensitization and Craving Data

\begin{tabular}{lcllc}
\hline & $\begin{array}{c}\text { Sensitization } \\
\text { (Increase in } \\
\text { Symptoms) }\end{array}$ & $\begin{array}{c}\text { Tolerance } \\
\text { (Decrease in } \\
\text { Symptoms) }\end{array}$ & $\begin{array}{c}\text { No } \\
\text { Change }\end{array}$ & $\begin{array}{c}\text { Not } \\
\text { Experienced }\end{array}$ \\
\hline Euphoria & $2(13.3 \%)$ & $8(53.3 \%)$ & $5(33.3 \%)$ & $0(0 \%)$ \\
Jitteriness & $10(66.7 \%)$ & $2(13.3 \%)$ & $3(20.0 \%)$ & $0(0 \%)$ \\
Increased & $2(13.3 \%)$ & $7(46.7 \%)$ & $6(40.0 \%)$ & $0(0 \%)$ \\
$\quad$ Libido & $9(60.0 \%)$ & $1(6.7 \%)$ & $4(26.7 \%)$ & $1(6.7 \%)$ \\
Referentiality & $9(60.0 \%)$ & $3(20.0 \%)$ & $3(20.0 \%)$ & $0(0 \%)$ \\
Delusions & $3(20.0 \%)$ & $0(0 \%)$ & $1(6.7 \%)$ & $12(73.3 \%)$ \\
Hallucinations & $0(0 \%)$ & $0(0 \%)$ & $0(0 \%)$ & $15(100 \%)$ \\
Seizures & None & Mild & Moderate & Severe \\
Craving & $4(26.7 \%)$ & $7(46.7 \%)$ & $3(20.0 \%)$ & $1(6.7 \%)$ \\
\hline
\end{tabular}

$\mathrm{N}$ (\% of population). Sensitization represents a reported increase in symptom, tolerance represents a reported decrease in symptom, as measured by a sensitization questionnaire (Bartlett et al., 1997). Craving data was collected with the Brief Substance Craving Scale. All information was collected in the hour prior to testing.

$20 \mathrm{msec}$ prepulse of pure tone followed by the 116 $\mathrm{dB}[\mathrm{A}]$ pulse. All pure tones had a frequency of $1000 \mathrm{~Hz}$.

All stimuli were delivered through headphones and were superimposed over $70 \mathrm{~dB}[\mathrm{~A}]$ white noise ("background noise") which was continued throughout the session. Stimuli were presented in six blocks of twelve trials (three of each trial type per block) for a total of 72 trials per session. Intertrial intervals varied from 15 to 45 seconds (30 sec average). All trials were presented in random order. The total session length was approximately $35 \mathrm{~min}$.

Startle responses were measured from the right orbicularis occuli muscle. Recordings were made using two $\mathrm{Ag} / \mathrm{AgCl}$ electrodes positioned under the eye. A third grounding electrode was placed behind the right ear, over the mastoid. Impedance was checked prior to testing, and the electrodes were repositioned if the impedance was greater than $6 \mathrm{k}$ Ohms. Electromyographic activity was amplified, digitized and stored for analysis.

\section{Data Analysis}

Mean startle response data for each subject in each block were calculated. Percent inhibition was calculated as pulse alone amplitude minus prepulse amplitude, divided by pulse alone amplitude times 100 [((PA-PP)/PA $\left.)^{*} 100\right]$. Response latencies were recorded as latency from stimulus presentation to blink onset (ONSET) and peak blink amplitude (PEAK). ANOVAs (Macintosh STATISTICA 4.1; Statsoft, Inc., Tulsa OK) were used to compare pulse alone amplitude, percent inhibition, and latency between the normals and the cocaine users. Subjects were dropped from analysis of PPI if they had an average pulse alone amplitude of 25 units or less during the first two blocks, but were included in analyses of pulse alone responses as per criteria of Braff et al. (1992). This manipulation was done to circumvent a "floor" effect, given that the prepulse calculation is based on a lower startle amplitude in the prepulse trials than in the pulse alone trials.

\section{RESULTS}

\section{Pulse Alone Amplitude}

Chronic cocaine users exhibited markedly diminished pulse alone startle amplitudes (mean $=54.4 \pm 4.8 \mathrm{am}$ plitude units) throughout the test session when compared to normal control subjects (mean $=169.1 \pm 21.2$ amplitude units) across all six blocks. A two-way ANOVA (group $\times$ block) analysis of pulse alone amplitude data for blocks 1-6 was significant for group ( $\mathrm{F}=$ $7.4 ; \mathrm{df}=1,22 ; p<.01$ ) (Figure 1). There was a significant group $\times$ block interaction $(\mathrm{F}=3.1 ; \mathrm{df}=5,110 ; p<$ .01 ), indicating that cocaine users and normal controls habituated differently. Normals showed significant habituation of pulse alone startle amplitude over successive blocks (from $218.8 \pm 51.7$ to $100.0 \pm 29.4$ amplitude units; $\mathrm{F}=3.7 ; \mathrm{df}=5,40 ; p<.007)$. Cocaine users exhibited a non-significant $(p<.14)$ decrease in pulse alone amplitude (from $71.6 \pm 21.0$ to $34.9 \pm 14.5$ amplitude units) (Figure 1).

When low startlers ( $n=5$, all in the cocaine group) were excluded from the analysis (see exclusion criteria above), the group effect on pulse alone amplitude was no longer significant $(p<.08)$. A $t$-test indicated that low startlers were in the same age range as startlers $(47.0 \pm 9.8$ (low startlers, $n=5)$ vs. $41.3 \pm 7.1$ years (startlers, $n=10), p<.22$ ).

\section{Prepulse Inhibition}

Subjects who had adequate startle responses (controls, $n=9$, cocaine users, $n=10$ ) were included in the calculation of PPI (see exclusion criteria above).

Prepulse data from the first three blocks only was subjected to complete analysis due to high variability and habituation confounds in the final three blocks (for Block 1, see Figure 2; data for other blocks not shown). While cocaine users exhibited enhanced gating in all 


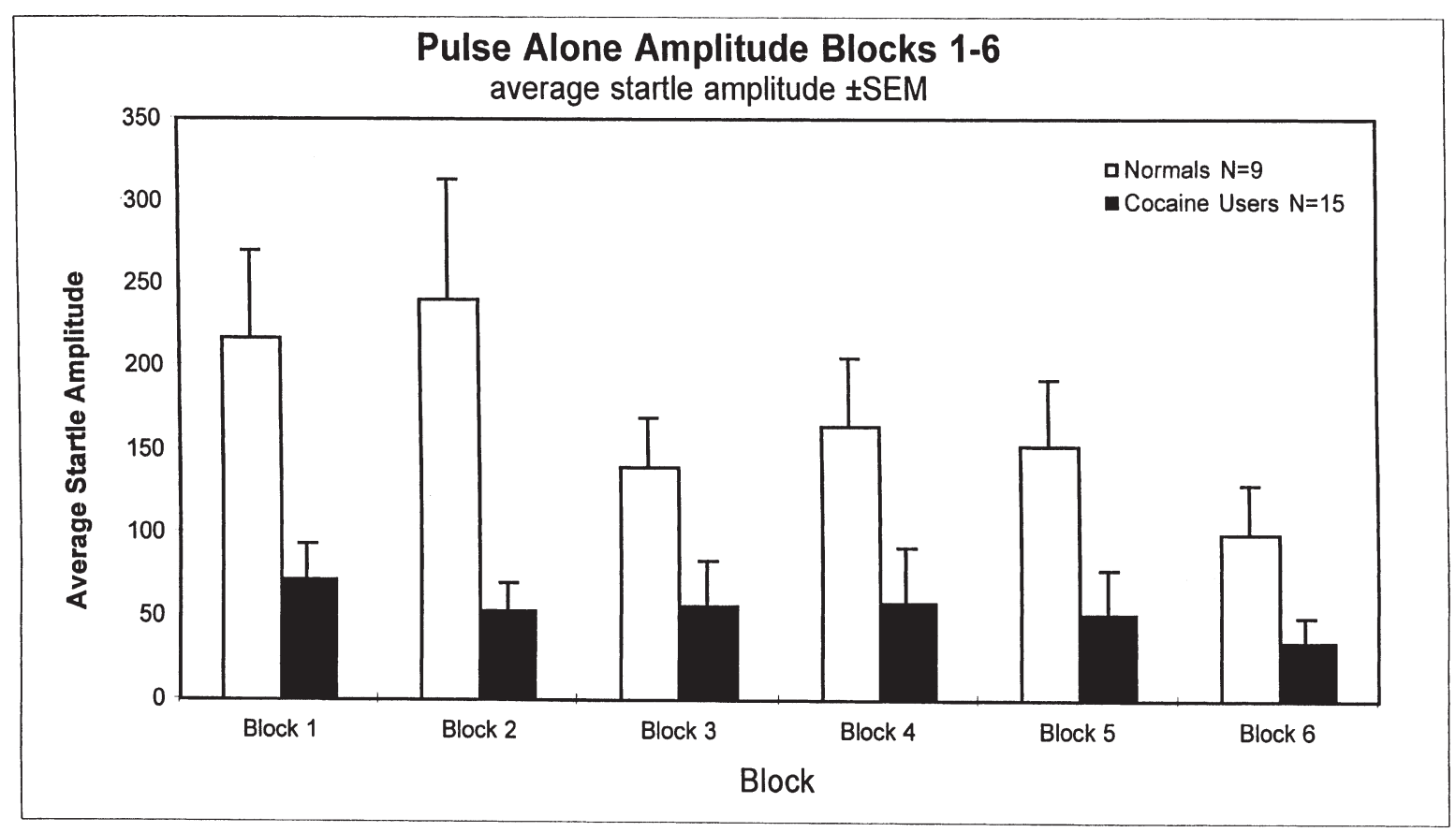

Figure 1. Pulse alone amplitude across 6 blocks, cocaine users vs. normal controls. Cocaine users startled significantly less than normal controls. Two way ANOVA: $\mathrm{F}=7.4 ; \mathrm{df}=1,22: p<.01$.

prepulse conditions, statistical significance was reached under one condition only. A three way ANOVA (Group $\times$ Block $\times$ Prepulse intensity) revealed a main effect of trial type ( $\mathrm{F}=42.7 ; \mathrm{df}=2,32 ; p<.0001)$, showing that the trial with the greatest prepulse intensity (85 $\mathrm{dB}$ ) accounted for the greatest percent inhibition in both groups. There were no significant group effects. There was a marginally significant group $\times$ block $\times$ trial type interaction $(\mathrm{F}=2.5 ; \mathrm{df}=4,64, p<.054)$, indicating that cocaine users responded differently to varying trial types in different blocks as compared to normals. Newman-Keuls post-hoc analysis indicated cocaine users inhibited more than normals under the $75 \mathrm{~dB}$ condition across the first three blocks (data not shown).

Group $\times$ Block and Group $\times$ Intensity interactions were not significant in the overall design, indicating that PPI responses were stable between groups over successive blocks and changing intensities.

A two-way (Group $\times$ Trial type) ANOVA on percent inhibition in block 1 only revealed a significant trial type effect $(\mathrm{F}=18.2 ; \mathrm{df} 2,34 ; p<.0001)$ and a significant Group $\times$ Trial type interaction $(\mathrm{F}=3.6$; df 2,34; $p<.04)$ (Figure 2). Newman Keuls post-hoc analysis indicated significantly higher percent inhibition in the cocaine group under the $75 \mathrm{~dB}$ prepulse condition $(p<.0007)$.

\section{Response Latencies}

Response data from subjects who met the above criteria was used for all analyses (cocaine users, $n=10$, nor- mals, $n=9$ ). ONSET data from the first three blocks was averaged for each trial type and subjected to a twoway Group $\times$ Prepulse intensity ANOVA. The same analysis was performed for PEAK. There were no significant differences in either PEAK or ONSET between normals and cocaine users. A Group $\times$ Block (three levels) $\times$ Prepulse intensity (three levels) three-way ANOVA was also not significant for group differences in either the PEAK or ONSET variables.

The $t$-tests indicated that all subjects exhibited shorter PEAK and ONSET latencies in prepulse trials as compared to pulse alone trials for all prepulse intensities (PEAK $p<.0001$, ONSET $p<.03$ ), demonstrating in effect that the prepulse lead to facilitation of peak and onset latency.

\section{Clinical Correlations}

For the cocaine users, the correlation between years of cocaine use and startle amplitude to pulse alone stimuli was nonsignificant $(r=0.34)$, as was the correlation between age and startle amplitude $(r=0.17)$.

\section{DISCUSSION}

The major finding of this study was that chronic cocaine users abstinent for three days to six months had markedly diminished acoustic startle responses. Additionally, prepulse inhibition was modestly enhanced in 


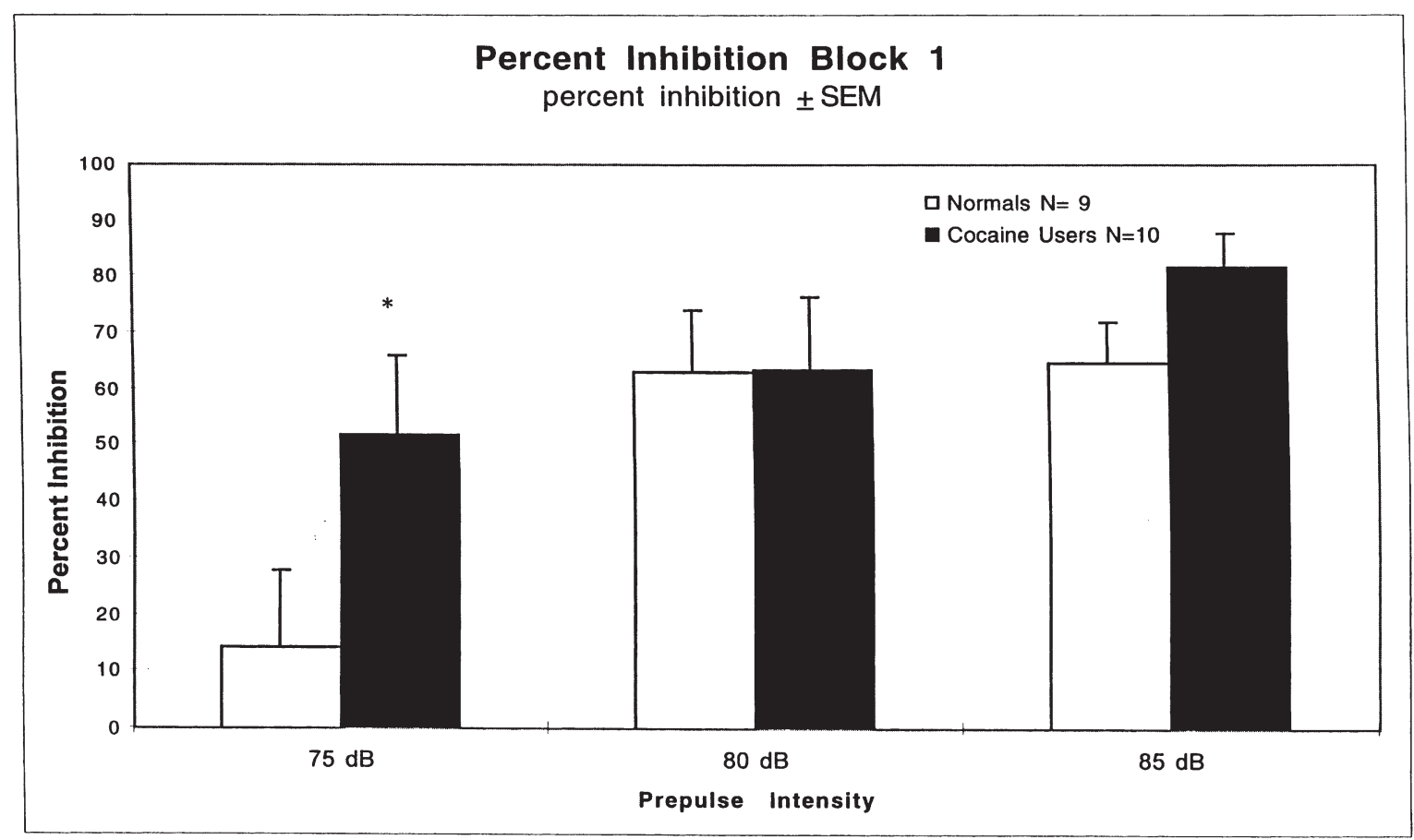

Figure 2. Percent prepulse inhibition in block 1, cocaine users vs. normal controls. Cocaine users had a significantly higher percent inhibition in the $75 \mathrm{~dB}$ condition only, as indicated by Newman Keuls post-hoc analysis $\left({ }^{*} p<.0007\right.$ compared to normal controls).

cocaine users under certain parameters. There were no differences in startle latencies between normal controls and cocaine users.

The cocaine using subjects in this study had been robust users for many years (mean $=16.7$ ), so that the neurochemical alterations which follow chronic cocaine use had more than adequate time to develop. They were relatively free of dependence on other substances of abuse, and none were known to be HIV positive. They were also screened to eliminate major Axis I psychopathology other than a history of substance-induced symptoms at times of heavy drug use in the past. Thus we presume that the diminished startle amplitudes in this group were attributable to their history of prolonged, heavy cocaine use. In the cocaine using group, neither age nor years of cocaine use was significantly correlated with startle amplitude; however our small sample size limits the generalizability of this negative finding.

Half of the cocaine using subjects were in a state of mild to moderate cocaine withdrawal at the time of testing as evidenced by their scores on the Cocaine Abstinence Symptoms Scoring Sheet (Table 2). Scores on the cocaine craving item of this scale (Table 3 ) indicate that two thirds of the cocaine subjects were experiencing mild to moderate cocaine craving at the time of testing.

Our findings on the Sensitization Assessment (Bartlett et al. 1997) indicated that a majority of cocaine subjects had sensitized to cocaine with regard to jitteriness, referentiality, and delusions; a majority of hallucinators had experienced sensitization with regard to their hallu- cinations. In contrast, we found a preponderance of tolerance to euphoria. This pattern is essentially in accord with the degree of sensitization found by Bartlett et al. (1997). Such a robust degree of symptom sensitization in our subjects may be an index of clinically meaningful neurochemical alterations with chronic cocaine use.

A small subset of subjects $(n=3)$ in this study had been abstinent from cocaine for a period of 4-6 months at the time of startle testing. Clinically, these individuals were not in a state of acute craving. These subjects showed diminished startle responses similar to those individuals who were tested within a week of cessation of cocaine use (the mean of startle amplitudes of these three individuals was within a standard deviation of the mean startle amplitudes of the newly abstinent subjects), indicating that altered startle responses may be reflective of persistent neurochemical alterations after cessation of drug use.

Imaging techniques such as positron emission tomography (PET), SPECT, and regional cerebral blood flow $(\mathrm{rCBF})$ have detected brain abnormalities in cocaine users, some of which persist well into abstinence. There is elevated glucose metabolism in the basal ganglia and orbitofrontal cortex in cocaine users; metabolism in the latter area and the prefrontal cortex correlates positively with cocaine craving in the first month of abstinence (Volkow et al. 1991). In a later study, Volkow et al. (1992) found decreased rates of frontal metabolism in cocaine dependent users which persisted after 3-4 months of detoxification. Cerebral perfusion as mea- 
sured by SPECT was reduced for up to six months after the start of cocaine abstinence (Strickland et al. 1993). Using the method of quantified EEG, Alper et al. (1998) found abnormal profiles in cocaine abusing subjects for up to six months of abstinence. Our finding of decreased startle amplitude may represent a functional concomitant to the changes reported in the above studies.

Cocaine administration is known to block dopamine reuptake, resulting in an acute increase in dopaminergic neurotransmission. Abstinence following a prolonged period of cocaine use leads to decreased dopaminergic activity as indicated by decreases in DA efflux (Parsons et al. 1991; Weiss et al. 1992), transporter mRNA expression (Pilotte et al. 1994), DAT in nucleus accumbens (Wilson et al. 1994), and $D_{1}$ receptor density (Kleven et al. 1990), suggesting a functional state of decreased dopaminergic neurotransmission (Kuhar and Pilotte 1996).

The robustly diminished startle amplitude to pulse alone stimuli which we observed in this sample of cocaine users is consistent with such a state of decreased DA neurotransmission. Acute administration of DA agonists such as cocaine, amphetamine, and apomorphine increases startle amplitude in rats (Kehne and Sorenson 1978; Davis 1980; Johansson et al. 1995; see Martinez et al. 1999), presumably as a result of increased DA neurotransmission. Acute administration of DA antagonists such as haloperidol or clozapine depress startle amplitude (Mansbach et al. 1988; Johansson et al. 1995). Since we tested only acoustic startle, it is unknown at present whether our results would be generalizable to other sensory modalities.

Likewise, our finding of enhanced gating in some conditions in cocaine users is consistent with reduced DA function. Acute administration of dopamine agonists disrupted PPI in several animal studies (Swerdlow et al. 1986; Mansbach et al. 1988; Peng et al. 1990; Davis et al. 1990). A similar effect on PPI was observed after direct administration of DA into the nucleus accumbens, a region implicated in stimulant abuse (Swerdlow et al. 1992). Furthermore, DA antagonists enhance PPI, particularly under conditions of weakest prepulse intensity (Swerdlow and Geyer 1993). In this context, it was our weakest prepulse condition which evidenced a significant difference in PPI between cocaine users and normals. It should be noted that the large differences we observed in startle amplitude could have by themselves confounded the calculation of PPI because of a floor effect, so that our PPI findings should be regarded as tentative. However, analyses across much larger datasets have failed to detect significant correlations between startle amplitude and calculated PPI (Duncan, unpublished data)

It is possible that our observed alterations in startle amplitude and PPI may be related to neurotransmitters other than DA. Acute cocaine administration has been shown to increase levels of serotonin through reuptake blockade (Ritz et al. 1990; Essman et al. 1994; Cunning- ham et al. 1996). Acute increases in 5-hydroxytryptamine (5HT) levels alone or via serotonergic agonists alter startle activity (Fechter 1974; Geyer et al. 1975; Davis 1980; Johansson et al. 1995), although serotonergic activity in the brain and the spinal cord may have opposite effects (Davis et al.1980; Astrachan and Davis 1981; Davis et al. 1986; Commissaris and Davis 1982). PPI is likewise sensitive to serotonergic stimulation (Mansbach et al. 1989; Martinez and Geyer 1997; Padich et al. 1996; Kehne et al. 1996; Vollenweider et al. 1999).

Alterations in norepinephrine (NE) activity must also be considered in the interpretation of our findings. Acute cocaine increases NE levels by reuptake blockade (Ritz et al. 1990). Acute NE stimulation increases startle amplitude (Davis 1980; Davis et al. 1982; Fendt et al. 1994). As is the case with serotonin, however, NE modulation of startle may occur within the spinal cord (Astrachan and Davis 1981; Adams and Geyer 1981). There have been conflicting reports concerning the effect of NE on PPI; Abduljawad et al. (1997) saw no changes in PPI, whereas Saitoh et al. (1986) noted significant alterations in PPI after NE stimulation.

The effects of 5HT and NE on startle and PPI notwithstanding, there is some indirect support for the idea that dopaminergic mechanisms are responsible for our findings. Withdrawal from chronic cocaine administration has been shown in rats to lead to only modest regional increases in NE receptor binding 30 days after drug administration, and no changes in 5HT binding (Belej et al. 1996). A PET study by Wang et al. (1995) showed no change in 5HT receptor availability in cocaine users as compared to normal controls, whereas the same group of subjects had robust changes in DA receptors (Volkow et al. 1993).

In summary, our findings of reduced startle amplitude and enhanced PPI in cocaine users are consistent with a state of decreased dopaminergic neurotransmission during early abstinence and complement the findings from other groups regarding brain abnormalities which persist into abstinence. Whether the changes detected in this study persist over months, eventually recover, or are predictive of long-term course may be clarified with further study in this area.

\section{ACKNOWLEDGMENTS}

The authors would like to thank Michael Sanfilipo for his assistance with statistical analyses of the data. This work was supported by NIDA/VA MDRU.

\section{REFERENCES}

Abduljawad KA, Langley RW, Bradshaw CM, Szabadi E (1997): Effects of clonidine and diazepam on the acous- 
tic startle response and its inhibition by 'prepulses' in man. J Psychopharmacol 11:29-34

Adams LM, Geyer MA (1981): Effects of 6-hydroxydopamine lesions of locus coeruleus on startle in rats. Psychopharmacology 73:394-398

Alper KR, Prichep LS, Kowalik SC, Rosenthal MS, John ER (1998): Persistent QEEG abnormality in crack cocaine users at 6 months of drug abstinence. Neuropsychopharmacology 19:1-9

Astrachan DI, Davis M (1981): Spinal modulation of the acoustic startle response: The role of norepinephrine, serotonin, and dopamine. Brain Res 206:223-228

Bartlett E, Hallin A, Chapman B, Angrist B (1997): Selective sensitization to the psychosis inducing effects of cocaine: A possible marker for addiction relapse vulnerability? Neuropsychopharmacology 16:77-82

Belej J, Manji D, Sioutis S, Barros HMT, Nobrega JN (1996): Changes in serotonin and norepinephrine uptake sites after chronic cocaine: Pre- vs. post withdrawal effects. Brain Res 736:187-196

Braff DL, Grillon C, Geyer MA (1992): Gating and habituation of the startle reflex in schizophrenic patients. Arch Gen Psychiatry 49:206-215

Commissaris RL, Davis M (1982): Opposite effects of N,Ndimethyltryptamine (DMT) and 5-Methoxy-N,N-Dimethyltriptamine (5-MeOMDT) on acoustic startle: Spinal vs. brain sites of action. Neurosci Biobehav Rev 6:515-520

Cunningham KA, Bradberry CW, Chang AS, Reith MA (1996): The role of serotonin in the actions of psychostimulants: Molecular and pharmacological analyses. Behav Brain Res 73:93-102

Davis M (1980): Neurochemical modulation of sensorymotor reactivity: Acoustic and tactile startle reflexes. Neurosci Biobehav Rev 4:241-263

Davis M, Astrachan I, Gendelman PM, Gendelman DS (1980): 5-Methoxy-N,N-Dimethyltriptamine: Spinal cord and brainstem mediation of excitatory effects on acoustic startle. Psychopharmacology 70:123-130

Davis M, Cassella JV, Wrean WH, Kehne JH (1986): Serotonin receptor subtype agonists: Differential effects on sensorimotor reactivity measured with acoustic startle. Psychopharm Bull 22:837-843

Davis M, Gendelman DS, Tischler MD, Gendelman PM (1982): A primary acoustic startle circuit: Lesion and stimulation studies. J Neurosci 2(6):791-805

Davis M, Mansbach RS, Swerdlow NR, Campeau S, Braff DL, Geyer MA (1990): Apomorphine disrupts the inhibition of acoustic startle induced by weak prepulse in rats. Psychopharmology 102:1-4

Essman WD, Singh A, Lucki I (1994): Serotonergic properties of cocaine: effects on a 5-HT2 receptor mediated behavior and on extracellular concentrations of serotonin and dopamine. Pharmacol Biochem Behav 49:107113

Fendt M, Koch M, Schnitzler H-U (1994): Amygdaloid noradrenaline is involved in the sensitization of the acoustic startle response in rats. Pharmacol Biochem Behav 48:307-314

Fechter LD (1974): The effects of L-dopa, clonidine, and apomorphine on the acoustic startle response in rats. Psychopharmacologia 39:331-344
Geyer MA, Warbritton JD, Menkes DB, Zook JA, Mandell AJ (1975): Opposite effects of intraventricular serotonin and bufotenin on rat startle responses. Pharmacol Biochem Behav 3:687-691

Graham FK (1975): The more or less startling effects of weak prestimuli. Psychophysiology 12:238-248

Hoffman HS, Searle JL (1968): Acoustic and temporal factors in the evocation of startle. J Acoust Soc Am 43:269-282

Izenwasser S, Cox BM (1990): Daily cocaine treatment produces a persistent reduction of $[3 \mathrm{H}]$ dopamine uptake in vitro in rat nucleus accumbens but not in striatum. Brain Res 531:338-341

Johansson C, Jackson DM, Zhang J, Svensson L (1995): Prepulse inhibition of acoustic startle, a measure of sensorimotor gating: Effects of antipsychotics and other agents in rats. Pharmacol Biochem Behav 52(4):649-654

Kehne JH, Padich RA, McCloskey TC, Taylor VL, Schmidt CJ (1996): 5-HT modulation of auditory and visual sensorimotor gating. 1. Effects of 5-HT releasers on sound and light prepulse inhibition in Wistar rats. Psychopharmacology 124:95-106

Kehne JH, Sorenson CA (1978): The effects of pimozide and phenoxybenzamine pretreatments on amphetamine and apomorphine potentiation of the acoustic startle response in rats. Psychopharmacology 58:137-144

Kleven MS, Perry BD, Woolverton WL, Seiden LS (1990): Effects of repeated injections of cocaine on D1 and D2 dopamine receptors in rat brain. Brain Res 532:265-270

Koch M, Kungel M, Herbert H (1993): Cholinergic neurons in the pedunculopontine tegmental nucleus are involved in the mediation of prepulse inhibition of the acoustic startle response in the rat. Exp Brain Res 97:71-82

Kuhar MJ, Pilotte NS (1996): Neurochemical changes in cocaine withdrawal. Trends Pharm Sci 17:260-264

Laurier LG, Corrigall WA, George SR (1994): Dopamine receptor density, sensitivity and mRNA levels are altered following self-administration of cocaine in the rat. Brain Res 634:31-40

Malison RT, Best SE, van Dyck CH, McCance EF, Wallace EA, Laruelle M, Baldwin RM, Seibyl JP, Price LH, Kosten TR, Innis RB (1998): Elevated striatal dopamine transporters during acute cocaine abstinence as measured by $\left[{ }^{123} \mathrm{I}\right]$ Beta CIT-SPECT. Am J Psychiatry 155:832-834

Mansbach RS, Braff DL, Geyer MA (1989): Prepulse inhibition of the acoustic startle response is disrupted byNethyl-3,4-methylenedioxyamphetamine (MDEA): in the rat. Eur J Pharmacol 167:49-55

Mansbach R, Geyer MA, Braff DL (1988): Dopaminergic stimulation disrupts sensorimotor gating in the rat. Psychopharmacology 94:507-514

Martinez ZA, Ellison GD, Geyer MA, Swerdlow NR (1999): Effects of sustained cocaine exposure on sensorimotor gating of startle in rats. Psychopharmacology 142:253260

Martinez DL, Geyer MA (1997): Characterization of the disruptions of prepulse inhibition and habituation of startle induced by alpha-ethyltryptamine. Neuropsychopharmacology 16:246-255 
Padich RA, McCloskey TC, Kehne JH (1996): 5-HT modulation of auditory and visual sensorimotor gating. II. Effects of the 5-HT2A antagonist MDL 100,907 on disruption of sound and light prepulse inhibition produced by 5-HT agonists in Wistar rats. Psychopharmacology 124:107-116

Parsons LH, Smith AD, Justice JB (1991): Basal extracellular dopamine is decreased in the rat nucleus accumbens during abstinence from chronic cocaine. Synapse 9: 60-65

Peng RY, Mansbach RS, Braff DL, Geyer MA (1990): A D2 dopamine receptor agonist disrupts sensorimotor gating in rats. Implications for dopaminergic abnormalities in schizophrenia. Neuropsychopharmacology 3:211-218

Pilotte NS, Sharpe LG, Kuhar MJ (1994): Withdrawal of repeated intravenous infusions of cocaine persistently reduces binding to dopamine transporters in the nucleus accumbens of Lewis rats. J Pharmacol Exp Ther 269:963-969

Ritz MC, Cone EJ, Kuhar MJ (1990): Cocaine inhibition of ligand binding at dopamine, norepinephrine, and serotonin receptors: a structure-activity study. Life Sci 46:635-645

Saitoh K, Shaw S, Tilson HA (1986): Noradrenergic influence on the prepulse inhibition of acoustic startle. Toxicol Lett 34:209-216

Strickland TL, ViLanueva-Meyer J, Miller BL, Cummings J, Mehringer CM, Satz P, Myers H (1993): Cerebral perfusion and neuropsychological consequences of chronic cocaine use. J Neuropsychiat Clin Neurosci 5:419-427

Swerdlow NR, Braff DL, Geyer MA, Koob GF (1986): Central dopamine hyperactivity in rats mimics abnormal acoustic startle response in schizophrenics. Biol Psychiatry 21:23-33

Swerdlow NR, Caine BC, Geyer MA. (1992): Regionally selective effects of intracerebral dopamine infusion on sensorimotor gating of the startle reflex in rats. Psychopharmacology 108:189-195

Swerdlow NR, Geyer MA (1993): Clozapine and haloperidol in an animal model of sensorimotor gating deficits in schizophrenia. Pharmacol Biochem Behav 44:741-744

Swerdlow NR, Keith VA, Braff DL, Geyer MA (1991): The effects of spiperone, raclopride, SCH 23390 and clozapine on apomorphine-inhibition of sensorimotor gating of the startle response in the rat. J Pharmacol Exp Ther 256:530-536

Volkow ND, Fowler JS, Wolf AP, Hitzemann R, Dewey S, Bendreim B, Alpert R, Hoff A (1991): Changes in brain glucose metabolism in cocaine dependence and withdrawal. Am J Psychiatry 148:621-626

Volkow ND, Hitzemann R, Wang C, Fowler JS, Wolf AP, Dewey SL, Handleman L (1992): Long-term frontal brain metabolic changes in cocaine abusers. Synapse 11:184-190

Volkow ND, Fowler JS, Wang G, Hitzemann R, Logan J, Schyler DJ, Dewey SL, Wolf AP (1993): Decreased dopamine D2 receptor availability is associated with reduced frontal metabolism in cocaine abusers. Synapse 14:169-177

Vollenweider FX, Remensberger S, Hell D, Geyer MA (1999): Opposite effects of 3,4-methylenedioxymethamphetamine (MDMA) on sensorimotor gating in rats vs. healthy humans. Psychopharmacology 143:365-372

Wang GJ, Volkow ND, Logan J, Fowler JS, Schyler D, MacGregor R, Hitzmann RJ, Gjedde A, Wolf AP (1995): Serotonin 5-HT2 receptor availability in chronic cocaine abusers. Life Sci 56:PL299-301

Wamsley JR, Alburges ME (1993): Cocaine causes a time dependant and dose dependant increase in D1 receptors and dopamine transporters. Proc West Pharmacol Soc 36:277-282

Weiss F, Paulus MP, Lorang MT, Koob GF (1992): Increases in extracellular dopamine in the nucleus accumbens by cocaine are inversely related to basal levels: Effects of acute repeated administration. J Neurosci 12:4372-4380

Wilson JM, Nobrega JN, Carroll ME, Niznik HB, Shannak K, Lac ST, Pristupa ZB, Dixon LM, Kish SJ (1994): Heterogeneous subregional binding patterns of [3H]-WIN 35, 428 and $[3 \mathrm{H}] \mathrm{GBR} 12,935$ are differently regulated by chronic cocaine self-administration. J Neurosci 14:29662979

Wolfsohn R, Sanfilipo M, Angrist B (1993): A placebo-controlled trial of L-DOPA/ Carbidopa in early cocaine abstinence. Neuropsychopharmcology 9:49-53 